\title{
Justice obtained? How disabled claimants fare at Employment Tribunals
}

\author{
Laura William, Birgit Pauksztat and Sue Corby
}

Manuscript accepted for publication in Industrial Relations Journal

May 2019

\begin{abstract}
This article explores disability discrimination cases at British Employment Tribunals. Analysing over 750 judgments, it examines the characteristics of claimants and the factors associated with the failure of cases: restrictive judicial decisions, complex legal tests, inequality of arms between claimant and employer and the stigma attached to claimants with mental impairments, providing some evidence for a hierarchy of impairments.
\end{abstract}

\section{Keywords}

Disability Discrimination; Employment Tribunals; Equality; Law; Legislation; Stigma

\section{Acknowledgments}

We would like to thank the anonymous reviewer for the thoughtful suggestions, and Marijtje van Duijn for helpful discussions of the analyses.

\section{Introduction}

Across the globe disabled people face discrimination in the labour market. Partly, discrimination is the result of individual actions against a disabled person or a group of disabled people (Foster and Scott, 2015; William, 2016), and partly it is the result of structural inequalities in society (Oliver, 2013). In response, many governments intervene to provide statutory rights to protect individuals against discrimination and in Britain this protection is provided through the Equality Act 2010. This Act prohibits discrimination on many grounds including disability, with an individual claim to an Employment Tribunal being the main avenue for redress.

Previous research on discrimination at Employment Tribunals focused on all types of discrimination combined, rarely distinguishing disability separately (Harding et al., 2014). Where disability discrimination cases have been studied, this has been at the Employment Appeals Tribunal stage (see: Konur (2007) and Lockwood et al. (2013-14; 2014)). This article, therefore, breaks new ground as it focuses solely on disability discrimination cases at first instance, Employment Tribunals.

In this article we address two research questions. First, what are the characteristics of those bringing disability discrimination claims to an Employment Tribunal? Second, why do 
disability discrimination claims fail? To this end, we analysed all disability discrimination judgments issued by Employment Tribunals in England and Wales for three calendar years, 2015 to 2017 inclusive.

Our analyses show that most claims fail. The factors associated with failure include restrictive court decisions around time limit extensions, complex tests of disability status, and the claimant having less expert representation than the employer. We contribute to the literature in two key ways, firstly we locate the processes and outcomes of disability discrimination cases in stigma theory and secondly we provide evidence that there is a hierarchy of impairments with those with mental health impairments faring worse than those with physical impairments in some crucial respects.

The paper is organised as follows. We start by setting our study in the stigma literature and considering the barriers to justice. Then briefly we discuss the Employment Tribunal process. Next, we present our methods and findings, concluding with a discussion of the findings and a consideration of some policy implications.

Stigma and barriers to justice

Goffman (1963), in his seminal work on stigma, defined stigma as the situation of the individual who is barred from full social acceptance either because of abomination of the body, blemishes of individual character, or tribal issues e.g. race (Goffman 1963:9). While Goffman's work focused on micro level interactions, recent work focuses on stigma at a macro level, particularly stigma as a form of social control and the lack of power inherent in stigma, which excludes stigmatised people from economic and social life (Link and Phelan, 2014; Solanke, 2017). Stigma can, therefore, be defined as the disadvantage that results from labelling, stereotyping, status loss and discrimination which occurs in an environment that pardons such treatment because of the low social and economic power of the stigmatised group (Solanke, 2017; Link and Phelan, 2014) and disabled people meet this definition.

We focus here on employment discrimination for which the main remedy is an individual filing a complaint to an Employment Tribunal after discrimination has occurred, a reactive, not a proactive approach. Solanke (2017) argues that this individual complaints model is unfit to address the stigma underpinning discrimination, while Dickens (2012:2) calls it a 'selfservice' approach. It is a form of privatised social justice (Ford, 2018: 6), as the state merely provides a forum and sets the procedural rules where individuals must have knowledge of their rights to launch a claim. Meager et al. (2002) show that white, male, better qualified, white collar employees with permanent jobs are most aware of their rights; however, they are also least likely to be stigmatised.

Solanke (2017) also argues that some stigmatised characteristics, for instance obesity, are not legally protected and where they are protected, there is a hierarchy: more attention is paid to race and gender, than to mutable characteristics such as religion. Importantly disability (which can be mutable or immutable) is the only protected characteristic where there is a prescribed, elaborate and multi-pronged legal test which disabled claimants must meet before they can start to prove discrimination and Goss et al. (2000) call this a double hurdle. The test (Equality Act 2010, s.6) is as follows: 
'A person $(\mathrm{P})$ has a disability if -

a) P has a physical or mental impairment, and

b) the impairment has a substantial and long-term adverse effect on P's ability to carry out normal day-to-day activities. ${ }^{1}$

An impairment is long term if it has lasted, or is likely to last for at least 12 months.

Konur (2007), analysing Employment Appeal Tribunal judgments, argues that strict tests of disability status prevented disabled employees from receiving legal protection, while Lawson (2011) submits that the requirement for a disability to have an adverse effect on 'normal activities' is particularly problematic. This narrow focus is termed 'legal blindness'; it is not the impairment itself that gives rise to discrimination but the social meaning attached to the impairment that causes discrimination, facilitated by stigma.

As well as a hierarchy between those who are afforded legal protection against discrimination, Harpur et al. (2017) argue that there are hierarchies of impairment within disability. In Britain, until 2005, mental and physical impairments were treated differently: a mental impairment had to be 'clinically well recognised' to receive protection. Over a decade later, Harpur et al. (2017) found that claimants with mental health impairments were less likely to obtain compensation than those with physical impairments. Similarly, Lockwood et al. (2014) found that appellants with a mental health impairment fared worse than those with physical impairments, while Taylor (2002) reported that it was more difficult for a claimant with a mental impairment to meet the definition of disability than a claimant with a physical impairment. This study, therefore, examines Employment Tribunal judgments on disability for evidence of a hierarchy of impairments.

The test of disability and the type of impairment may not be the only barriers to justice. Maroto and Pettinicchio (2014) argued that limited enforcement and judicial resistance is a key barrier to justice. Judicial resistance is where conservative court decisions limit the intentions of the law, whether or not the rules are barriers themselves. For example, Marinescu (2011) considered Employment Tribunal claims and found the higher the unemployment and the bankruptcy rates, the less likely judges were to rule in favour of the employee. This finding, however, was based on unfair dismissal cases in 1992 and did not cover discrimination claims. Hepple (1987) argues that judges' lack of knowledge and experience of discrimination law, and of the skills of fact finding in cases where there is rarely direct evidence of discrimination, are a barrier to justice. He cites Leonard (1987) who found that the legislation on sex discrimination was misunderstood and misapplied by judges. We examine whether or not there is evidence of these barriers to justice in our study.

Finally, we consider whether a stand-alone disability claim is more likely to succeed than a disability claim brought concurrently with other claims such as discrimination on the grounds of other protected characteristics such as race and/or gender. Lockwood et al. (2013-2014: 143), analysing Employment Appeal Tribunal cases and concentrating on mental health discrimination cases only, found that 'the success rate falls sharply where more than one additional claim is made'. In our data, do we find evidence of disabled claimants bringing

\footnotetext{
${ }^{1}$ A non-exhaustive list of normal day to day activities is given in Guidance on the Definition of Disability 2011.
} 
more than one additional claim and, if so, how does this affect a disabled claimant's success at an Employment Tribunal?

\section{Taking a case}

\section{Insert Figure 1 about here}

To bring a case successfully, a claimant must follow the required legal process in an Employment Tribunal and Figure 1 sets this out in a simplified form. First, a claimant must notify the Advisory, Conciliation \& Arbitration Service (ACAS), which seeks to broker a voluntary, 'early conciliation' settlement between employer and claimant. In 2016-2017 ACAS received 10,282 notifications of disability discrimination (ACAS, 2018). ${ }^{2}$ Of these many are resolved or withdrawn, there being little or no difference between potential disability cases compared to other cases. In 2015-16, 19 per cent of disability discrimination cases were resolved, compared to 22 per cent of all cases and the equivalent figures for 201617 were 32 per cent of disability discrimination cases compared to 30 per cent for all cases (ACAS, 2019).

The next step is for a claimant to start proceedings in an Employment Tribunal by completing a prescribed form (ET1) within strict time limits. For disability cases the time limit is three months minus one day of the date of discrimination or the last date when a continuing act of discrimination occurred. The respondent, the relevant employer, is asked by the Employment Tribunal to respond, using a prescribed form (ET3).

All Employment Tribunal cases have to have a preliminary hearing, which is normally held in public in disability cases as jurisdictional issues, such as time limits or disability status, can be considered, not just case management arrangements (ETS (Constitution \& Rules of Procedure 2013) Schedule 1, Rule 53). If a claimant's case has not been disposed at a preliminary hearing, the case can proceed to a full hearing where the judge is joined by two lay members, one drawn from an employee panel and the other drawn from an employer panel.

At this hearing, various types of discrimination which are not mutually exclusive, have to be separately claimed (Table 1) and proved according to complex provisions on the burden of proof. Direct discrimination claims and claims of discrimination arising from disability are brought by individuals who argue they have been directly stigmatised, whereas indirect discrimination is the result of structural or institutional practices that result in discrimination. A further type is where discrimination is alleged because the employer has failed to provide a reasonable adjustment for the disabled employee e.g. shorter working hours or adjustments to physical premises. ${ }^{3}$ Such a legal provision, which may involve treating the disabled person more favourably than their non-disabled colleagues, is rarely understood by employers, but

\footnotetext{
${ }^{2}$ Conciliation, as opposed to early conciliation, can be provided at any time up to the Employment Tribunal hearing

${ }^{3}$ Common examples of reasonable adjustments include starting work later to avoid travelling in peak times, the provisions of ramps to access buildings and text to speech software.
} 
unless adjustments are made, disabled people experience disadvantage and failure to make reasonable adjustments can be claimed (William, 2016).

Insert Table 1 about here

If any part of a claimant's claim is successful, compensation can be awarded for material loss and injury to feelings, but in practice compensation is modest: the median in the year from April 2017 was £16,523 (Ministry of Justice, 2019) and because Employment Tribunals have no power to enforce their money judgments, claimants may not even receive their award.

A full hearing can last more than 20 days (Burgess et al., 2017), while according to HM Courts and Tribunals Service, the average time between starting a claim and receiving a decision is 26 weeks (Kenner, 2018), so an Employment Tribunal case 'is likely to be a stressful experience, particularly for a non-represented party’ (Morris, 2012: 18).

Furthermore, to engage in such a process, claimants need access to financial resources. Between 2013 and 2017, a claimant had to pay $£ 1,200$ for a type B claim which included disability discrimination. Claimants who passed a capital and income test could receive fee remission in full or part, but less than half of claimants requested fee remission for a type $B$ claims and of those that did, only 30 per cent were successful (Ministry of Justice, 2016). This fee system, the Government admitted, bore disproportionately heavily on disabled claimants (Ministry of Justice, 2017).

Claimants also need financial resources if they want legal representation. Our analysis below will shed light on legal representation and the part it plays and on other factors associated with disabled claimants' success or failure at an Employment Tribunal. Having sketched the background, we now present our methods, data and results.

\section{Methods}

Our data includes all Employment Tribunal cases that went to a preliminary hearing or beyond in the three calendar years 2015-2017 inclusive, and is thus a census, not a sample. In all these cases the fee system applied when the claimant submitted their claim. This is because although Employment Tribunal fees were abolished by the Supreme Court's decision on 26.7.17, the time between the submission of a claim and the handing down of a judgment is on average six months (Kenner, 2018) as noted above, with discrimination cases often taking longer than this average. ${ }^{4}$ Accordingly, all the claimants in the cases we considered would have paid the issue fee of $£ 250$ (or obtained remission) when they filed the ET1 and either paid or expected to pay the hearing fee of $£ 950$.

Information on cases heard in 2015-2016 were collected at the Employment Tribunal register in Bury St Edmunds, England, by the first author. Bury St Edmunds holds a basic electronic

\footnotetext{
4 Citizens Advice Bureau https://www.citizensadvice.org.uk/work/problems-at-work/employmenttribunals/starting-an-employment-tribunal-claim/\#h-when-will-my-employment-tribunal-case-be-heard[accessed 4.2.19]
} 
database on all Employment Tribunal cases for England and Wales, filed by jurisdiction and case number. This database was searched to locate all DDA classified cases in 2015 and 2016 and to find the paper copy of the judgment. In some instances there was no paper copy of the judgment and the database had only very basic information such as claimant name and jurisdiction. Due to the very limited information available, these cases were not included.

In early 2017, the Ministry of Justice placed Employment Tribunal judgments online. Therefore, cases from 2017 were identified through the Ministry of Justice website, by searching for key terms '2017' and 'DDA'. The judgments were then downloaded and saved.

Cases where associative discrimination was claimed were removed as we wanted to focus on disabled claimants only. Also we removed cases that were withdrawn before a preliminary hearing because they usually contained little information beyond respondent, claimant and jurisdiction codes. All the cases that went to a preliminary hearing or beyond (762 cases) were then subject to content analysis.

A code book was developed based partly on the coding used in the Survey of Employment Tribunal Applications (Harding et al., 2014). Where available, information such as gender, impairment, representation, or type of discrimination pleaded, was coded for each case. However, occasionally we were unable to code every characteristic because information was missing or reported incompletely, or demographic information might have been removed from the judgment due to confidentiality agreements.

To assess the reliability of the coding, 100 cases were coded independently by the first and the third author. Interrater reliability was 97 per cent. Disagreements were resolved through discussion.

We used binary logistic regression analysis to examine whether the characteristics of a case affect its success, that is, what factors increased the likelihood that a case was successful at full hearing, rather than being withdrawn, settled or dismissed at any stage of the process? The dependent variable 'success at full hearing' was coded ' 1 ' for a case if one or more of the claims included in it were successful at the full hearing, and ' 0 ' otherwise. For the analysis, we used all available cases (Table 3).

As noted above, information on the nature of claimants' impairment was missing for 322 of the 762 cases in the dataset. To make use of the available data, we therefore conducted two analyses, namely one analysis without the information on impairment (Table 3: Model 1) and one analysis including the information on impairment (Model 2).

\section{Results}

Case characteristics

The data collection provided 762 cases for the analysis. As shown in Table 2, most claims were brought by men, employees in the private sector and individuals with physical impairments. Almost a fifth of the cases (18 per cent) included claims for other types of

\footnotetext{
${ }^{5}$ The jurisdiction code to identify any disability discrimination claims.
} 
discrimination. Table 2 shows the most common type of disability discrimination claimed was failure to make reasonable adjustments (336 claims), with only 83 claims for indirect discrimination.

Insert Table 2 about here

In addition, we investigated the experience of judges dealing with disability discrimination. Information on the identity of the judge was available for 745 cases. In total, 167 judges presided in those 745 cases, with the median being four cases per judge. 38 judges had one case, 77 judges had two to five cases, 43 judges had six to 10 cases, and nine judges had more than 10 cases, suggesting most judges had low levels of experience with disability discrimination cases. Just because judges have less experience, however does not necessarily equate to an inability to apply complex law.

Accordingly, we looked at appeals to the Employment Appeal Tribunal to see if the Employment Tribunal had made a mistake in law and thus whether more disability discrimination appeals were allowed compared to other types of appeal. Taking 2015-2017 together disability discrimination appeals were allowed at the same rate, 45 per cent, as all other appeals, but there were wide variations from year to year. In the calendar year 2016, 69 per cent of disability discrimination appeals were allowed compared to 46 per cent of other appeals, with the equivalent figures for 2017 being 20 per cent for disability discrimination appeals compared to 45 per cent for other appeals. ${ }^{6}$ In short, the appeal data does not support the contention that inexperienced judges misapply the law.

Table 2 shows claimant representation. The most common type of representation was legal representation (287 cases, 37.7 per cent), i.e. representation by barristers and solicitors. Following very close behind is self-representation, where a claimant did not have any representation ( 269 cases, 35.3 per cent). In 76 cases claimants used a lay representative, i.e. an individual without formal legal standing, such as a union official or a representative from a voluntary organisation. The remaining category is friends and family. As shown in Table 2, employers were twice as likely as claimants to have legal representation (78.7 per cent compared to claimants' 37.7 per cent).

We compared our findings with Buscha et al. (2012). They found that taking all jurisdictions together, 59.7 per cent of claimants had legal representation at a full hearing, compared to our figure of just over one third for disability discrimination. The equivalent figure for employers was 62.8 per cent.

Insert Figure 2 about here

\footnotetext{
${ }^{6}$ Allowed includes allowed and remitted. Unpublished data provided to the third author by the Operation Support Manager at the Employment Appeal Tribunal in an email dated 30.1.19.
} 


\section{Factors affecting the outcomes of discrimination cases at Employment Tribunals}

Given these case characteristics, at what stage do disability discrimination claims fail and why? As shown in Figure 2, disability discrimination claims had low success rates at Employment Tribunals in 2015-2017. Less than a fifth of all cases that went to a preliminary hearing were successful. Looking at full hearings alone, a claimant is almost three times more likely to fail than to succeed. There are a large number of cases that are withdrawn after a preliminary hearing. Few of these cases are settled.

We compared our findings with statistics on all cases brought to Employment Tribunals from the Ministry of Justice (2019) for the financial year 2016-17. These showed that 4 per cent of disability discrimination claims succeeded compared to 6 per cent of all claims brought to Employment Tribunals. However, this is calculated on the basis of all claims received, whereas our data include only claims that were accepted for a preliminary hearing. Therefore, the statistics cannot be compared.

Insert Table 3 about here

As shown in Table 3, we found that neither the claimants' gender, type of impairment, sector nor the judge's experience with disability discrimination cases had a significant association with the overall outcome of the case.

To address the question of equality of arms and the balance of representation as factors which could affect success, we examined whether a claimant and employer in the same case were equally matched. Accordingly, we rank ordered forms of representation from least expert (0) to most expert (3). Codes of 0 referred to those who did not attend and were not represented, 1 was used for self-representation or representation by friends and family, 2 for lay representation, and 3 for legal representation. Using these codes, we created two variables, one rating the expertness of representation for claimants, and one for employers. Next, we subtracted expertness of employers' representation from expertness of claimants' representation. This resulted in a new variable, 'equality of arms', with values ranging from 3 (employer has more expert representation) to 3 (claimant has more expert representation), with a midpoint of 0 (claimant and employer have equally expert representation). The data showed that employers generally had equally expert (273 cases, 35.8 per cent) or more expert representation (379 cases, 49.7 per cent) than claimants. Only in 30 cases (3.9 per cent), did claimants have more expert representation than the employer.

Equality of arms significantly increased claimants' likelihood of success at full hearing (Table 3). Indeed, claimants who were at least as equally well represented as the employer in the same case were significantly more likely to achieve a successful outcome at a full hearing (25 per cent) than those who were less well represented than the employer side (12 per cent; $t(680)=4.21, p<.001)$. Additional analyses showed that those who had legal representation were more likely to succeed ( 24 per cent) than those who did not have legal representation (13 per cent; $t(700)=3.65, p<.001)$. And conversely, those who represented themselves were less likely to succeed (12 per cent) than others (21 per cent; $t(700)=3.04, p<.01)$. 
We were unable to compare our findings with Buscha et al. (2012:49) on matched cases, as their data was based on a small number of unfair dismissal cases only and included day-today representation as well as representation at a hearing.

Further, we examined whether intersectionality played a role. We found that overall, cases that included other discrimination claims (such as discrimination for age, gender, or race) in addition to disability discrimination were less likely to be successful at full hearing than cases that did not include other discrimination claims (Table 3, Model 1).

Interestingly, the type of impairment had no effect on success at full hearing (Table 3, Model 2). However, the type of impairment did affect whether or not disability status was challenged, see below.

\section{Challenges and reasons for dismissal}

Many judgments included information on jurisdictional issues that the judge needed to rule upon such as whether the claims were submitted out of time, whether the claimant met the definition of disability, and if the employer knew the person was disabled. We examined this information where it was available.

First, we investigated the number of cases that were dismissed at a preliminary hearing because the disability discrimination claimed was submitted out of time. There were 755 cases where data was available on time limits. In 143 cases the disability discrimination claim was submitted out of time, but a judge has discretion to extend the time where it is 'just and equitable' to do so (Equality Act s.118(1)). In only a fifth of these cases (30 cases; 21.0 per cent), the judge extended the time limit, so the case could proceed. In the vast majority of cases (109 cases, 76.2 per cent) that were submitted out of time, the judge did not exercise his/her discretion to extend time limits. Therefore, claimants did not get to the stage where they were able to determine the substantive facts about the discrimination they alleged. Unfortunately, we were unable to find any statistics to determine whether judicial discretion over time limits is less rarely or more frequently exercised in disability discrimination cases, compared with other discrimination jurisdictions where the same judicial discretion applies.

In order for a case to progress past a preliminary hearing, commonly the claimant has to meet the strict Equality Act 2010 definition of disability in terms of the impairment, its severity, longevity and impact on day to day activities. If a claimant does not meet just one of these criteria they will be deemed 'not disabled' and the case will fail. In 2015-2017, 88 of the 762 cases in our data (11.5 per cent; information missing for 322 cases) failed because the claimant did not meet the definition of disability.

Examining the 377 cases for which both information on meeting the definition of disability and on the type of impairment is available, we found that claimants with physical and/or sensory impairments were significantly more likely to meet the definition of disability (87 per cent) than those without such impairments (77 per cent; $t(375)=2.37, p<.05$ ).

An employer defence is to mount a challenge to the disability status of the claimant. We examined 353 cases where information was available, including cases where the employer said that they had 'conceded' disability status because the Oxford English dictionary (n.d.) defines concede as 'admit or agree that something is true after first denying or resisting it'. 
We found that disability status was challenged in over half (200 cases; 56.7 per cent). Again, challenges were associated with certain types of impairment. Claimants with physical and/or sensory impairments were significantly less likely to be challenged (50 per cent) than those without such impairments (68 per cent; $t(333)=3.06, p<.01)$. In contrast, the disability status of those with mental impairments was significantly more likely to be challenged (67 per cent) than the status of those without mental impairments (48 per cent; $t(333)=3.70, p<$ $.001)$.

A further way that employers can escape liability for any discrimination that has occurred, is to say that they had no knowledge that the claimant was disabled at the material time. Again, we included cases where employers conceded. The results show that in 147 cases (out of 340 where data was available), the employer claimed lack of knowledge. Of the 147 cases where knowledge was disputed, in 103 cases (70.1 per cent) one or more types of disability discrimination were dismissed at a full hearing, and in 46 cases (31.3 per cent) one or more types of disability discrimination were successful at a full hearing.

Again, employers' claims of lack of knowledge of claimants' disability were associated with certain types of impairment. Employers of claimants with physical and/or sensory impairments were significantly less likely to be unaware of their disability (40 per cent) than those without physical impairments (51 per cent; $t(321)=1.99, p<.05$ ). By contrast, employers of claimants with mental impairments were significantly more likely to claim unawareness of their employees' disability (50 per cent) than those of claimants without mental impairments (39 per cent; $t(321)=2.04, p<.05)$.

Overall we can see that claimants without legal representation, who submit their claim out of time are more likely to fail at the Employment Tribunal. We show that employees with physical and/or sensory impairments are more likely to meet the definition of disability, least likely to have their disability status challenged and least likely that the employer claims lack of knowledge.

\section{Discussion and conclusions}

Our study, based on a unique dataset, considered the characteristics of claimants bringing disability discrimination claims to Employment Tribunals and analysed why claims fail. Meager et al. (2002) report that it is commonly white, male, better educated employees who are most likely to be aware of their legal rights and have the requisite knowledge to make a claim. Our data supports this finding: in the three years 2015-2017, more men than women brought a claim for disability discrimination. (We had no information on the ethnicity or the level of education of claimants.) We also found that more claims were brought in the private sector than in the public sector. This is in line with previous studies characterizing the public sector as more inclusive for minorities than the private sector (Van Wanrooy et al., 2013).

Our study shows that more claims of direct discrimination were brought than indirect discrimination claims and there was evidence that those claiming discrimination on other protected grounds in addition to disability (intersectional discrimination) were more likely to fail than those bringing stand-alone disability discrimination claims. 
Our study has highlighted the low success rates of disability discrimination Employment Tribunal cases. If a case gets past a preliminary hearing, the claimant is three times more likely to fail than to succeed at a full hearing. This low rate of success revealed in our data is comparable to the success rates reported in earlier studies (Roulstone, 2003; Konur, 2007), and should be considered together with the low levels of compensation normally awarded to those who succeed (Ministry of Justice, 2019). As a result, many employers could take away the message that they can safely ignore the employment rights of disabled persons where society condones the discrimination disabled people face because of the stigma attached to disabled people and their low social status and interpersonal power.

Given such low success rates of disability discrimination claims at Employment Tribunal our study examined the factors associated with the failure of cases. While Konur (2007) argues that it is the strictness of the rules that prevent disabled people securing justice, Maroto and Pettinicchio (2014) contend that it is judges' interpretations of law that prohibit successful claims at Employment Tribunals. Furthermore, Hepple (1987) reports that judges are inexperienced and, therefore, cannot correctly apply complex law.

Our study provides support for the first two of these reasons for cases failing at Employment Tribunals. Firstly, in line with Maroto and Pettinicchio (2014), the analysis shows evidence of restrictive judicial decisions where judges have chosen not to exercise their discretion to extend time limits and have applied the definition of disability narrowly. Secondly, in line with Konur (2007), this study shows that the restrictive legal rules themselves could obstruct justice for disabled people. This point is evidenced by the number of cases that were submitted out of time. If such a strict rule was not in place then the judge would not have to decide whether to extend the three months minus a day time limit.

Finally, the analysis shows evidence of judges having little experience of disability discrimination cases: the median number of cases heard by a judge in three years is four cases. This lack of experience supports the contention of Hepple (1987), that judges lack experience, but further research is needed to determine if this lack of experience results in a misapplication of the law by matching cases at appeal level to judges at the Employment Tribunal level.

Extant research identifies several ways in which the definition of disability in British law has proved to be problematic for disabled people. Our study expands earlier studies; we found that a challenge to the disability status of the claimant was an important and often successful tactic of employers to defeat a claim. In the majority of cases, where information was available, the employer either contested knowledge of disability and/or contested that the claimant was disabled. The claimant then had to present evidence to prove their disability. This finding is in line with Goss et al. (2000): claimants face a double hurdle as they first must prove disability before they can seek to prove that discrimination occurred.

While our study has shown that the rules themselves and their application by judges, can play a part in understanding the factors which explain why disability discrimination claims fail, it also contributes to the literature by including two other important factors: stigma and equality of arms.

Looking first at stigma: while existing research draws on stigma to debate a hierarchy of those protected in law compared to those who are not (Solanke, 2017), our study sought to 
discover whether there is a hierarchy between impairments as suggested by Harpur et al. (2017). Our analyses show that those with a physical impairment were less likely to have their disability status challenged and/or employers were less likely to claim lack of knowledge of the impairment compared to claimants with a mental impairment. This point may be because, as shown by Taylor (2002), mental impairments are more difficult to prove at an Employment Tribunal. Even though the definition of mental impairments has been relaxed since 2005, mental impairments are still poorly understood, while Harpur (2017) submits that claimants with mental impairments are more stigmatised than claimants with physical impairments.

We have already noted that stigma is associated with power and one way of gauging power at an Employment Tribunal is to analyse equality of arms, the balance of claimant versus employer representation in each matched case. This study has shown that the greater the power imbalance the more likely the employer is to win e.g. legal representation compared to the self-represented claimant. Such power imbalances reflects the power imbalance in the employment relationship (Dickens, 2012) and is a factor that has not been taken into account in the literature on the success rate of disability discrimination claims at Employment Tribunals.

In conclusion, this study indicates four factors associated with the failure of disability discrimination Employment Tribunal claims. Firstly, the nature of the law - the strict rules that claimants must follow hinders access to justice. Secondly, we presented evidence that judges often make restrictive jurisdictional decisions, for instance not exercising their discretion to extend time limits and applying the definition of disability narrowly. Thirdly, we have demonstrated that low success rates are associated with inequality in arms, where employers are more likely to have legal representation and thus more expert representation than the claimant. Finally, claimants with more stigmatised conditions, i.e. mental health, fare worse in terms of meeting the definition of disability, being challenged more often on their disability status and employers claiming lack of knowledge compared to claimants without mental impairments, suggesting a hierarchy in the way impairments are treated at Employment Tribunals.

\section{Policy implications and future research}

Based on our study's findings there are policy implications. Firstly, consideration should be given to the provision of legal aid at Employment Tribunals for disability discrimination cases, although we realise that this would impose a cost on the public purse. Given the complexity of disability discrimination law, ensuring legal representation would go some way to addressing the inequality of arms between claimant and employer which is a factor significantly associated with the failure of a case. Secondly, an extension to the time limits should be considered at least to the time limit of six months as in equal pay cases. Finally, there needs to be a change to the restrictive definition of disability in the Equality Act 2010 as in the Americans with Disabilities Amendments Act 2008 which inter alia does not require extensive analysis of the individual's impairment.

Further research could expand the analysis to include post 2017 cases to assess the impact of the removal of fees on cases. It could also match judges at the Employment Tribunal level to 
appeals, to see if lack of experience is associated with appeals being allowed. Moreover, the present study provides only an initial picture of the factors affecting the success of a case. Future studies could examine the outcomes of different disability discrimination claims nested in a particular case, and provide a more detailed understanding of the factors contributing to these outcomes, taking into account the sequential nature of the process as well as the multilevel structure of the data.

In this article we have focused on disability discrimination claims taken to Employment Tribunals, but such claims should not be considered in isolation and a holistic approach to combatting disability discrimination should be taken. In particular Corby et al. (2018) previously argued that if disability discrimination is to be reduced, proactive measures need to be embraced as well, including Britain adopting a quota/levy scheme in respect of the employment of disabled people, as in many countries in continental Europe.

\section{References}

ACAS. (2018) Annual Report 2017-2018. London: Advisory, Conciliation and Arbitration Service.

ACAS. (2019) Unpublished data provided to the $3^{\text {rd }}$ author by email dated 16.2.2019. London: Advisory, Conciliation and Arbitration Service.

Buscha, F., P. Urwin and P. Latreille (2012), 'Representation in Employment Tribunals: analysis of the 2003 and 2008 Survey of Employment Tribunal Applications (SETA)', Acas Research Paper 06/12, London: Advisory, Conciliation and Arbitration Service.

Burgess, P., S. Corby, A. Höland, et al. (2017) The roles, resources and competencies of employee lay judges: a cross-national study of Germany, France and Great Britain. Working Paper 051. Düsseldorf: Hans Böckler Stiftung.

Corby, S., L. C. William, and S. Richard (2018), 'Combatting disability discrimination: A comparison of France and Great Britain', European Journal of Industrial Relations, 25, 2, 41-56.

Dickens, L. (2012), 'Fairer workplaces: making employment rights effective', in: L. Dickens (ed), Making Employment Rights Effective. Oxford: Hart Publishing, pp. 205-288.

Ford, M. (2018), 'Employment Tribunal fees and the rule of law: R (Unison) v Lord Chancellor in the Supreme Court', Industrial Law Journal, 47, 1, 1-45.

Foster, D. and P. Scott (2015), 'Nobody's responsibility: the precarious position of disabled employees in the UK workplace', Industrial Relations Journal 46, 4, 328-343.

Goffman, E. (1963), Stigma: Notes on the managment of a spoiled identity, New York: Simon and Schuster.

Goss, D., F. Goss and D. Adam-Smith (2000), 'Disability and employment: a comparative critique of UK legislation', The International Journal of Human Resource Management, 11, 4, 807-821.

Harding, C., S. Ghezelayagh, A. Busby et al. (2014), Findings from the Survey of Employment Tribunal Applications 2013. London: Business Innovation and Skills.

Harpur, P., U. Connolly and P. Blanck (2017), 'Socially Constructed Hierarchies of Impairments: The Case of Australian and Irish Workers' Access to Compensation for Injuries', Journal of Occupational Rehabilitation, 27, 4, 507-519.

Hepple, B. (1987), Industrial Trbunals, a report by Justice. London: Justice.

Kenner, M. (2018), Employment tribunal claims up 90 per cent year on year. Available at: https://www.peoplemanagement.co.uk/news/articles/employment-tribunal-claimsincrease-90-percent. Accessed 09/03/18 
Konur, O. (2007), 'A judicial outcome analysis of the Disability Discrimination Act: a windfall for employers?' Disability \& Society, 22, 2, 187-204.

Lawson, A. (2011), 'Disability and employment in the Equality Act 2010: opportunities seized, lost and generated', Industrial Law Journal, 40, 4, 359-383.

Leonard, A. (1987), Judging inequality: the effectiveness of the tribunal system in sex discrimination and equal pay cases. London: Cobden Trust.

Link, B. and J. Phelan (2014), 'Stigma Power', Social Science \& Medicine, 103 (Feb), 49-65.

Lockwood, G., C. Henderson and G. Thornicroft (2013-14), 'Challenging Mental Health Discrimination in Employment', Journal of Workplace Rights, 17, 2, 137-152.

Lockwood, G., C. Henderson and G. Thornicroft (2014), 'Mental Health Disability discrimination: law, policy and practice', International Journal of Discrimination and the Law, 14, 3, 168-182.

Marinescu, (2011), 'Are Judges Sensitive to economic Conditions? Evidence from UK Employent Tribunals, Industrial and Labor Relations Review, 64, 4, 673-698.

Maroto, M. and D. Pettinicchio (2014), 'The Limitations of disability antidiscrimination legislation: policymaking and the economic well-being of people with disabilities', Law \& Policy, 36, 4, 370-407.

Meager, N., C. Tyres, S. Perryman, et al. (2002), Awareness, Knowledge and Exercise of Individual Rights. London: DTI.

Ministry of Justice (2016), Review of the introduction of fees in the Employment Tribunals Cm 9373. London: HMSO.

Ministry of Justice (2017), Review of Introduction of fees in the Employment Tribunals Consultation on proposals for reform, Cm 973. London: Ministry of Justice.

Ministry of Justice (2019), Percentage of disposals by outcome and jurisdiction 2007/08 to 2017/18. London: Ministry of Justice.

Morris, G. (2012), 'The development of statutory employment rights in Britain and enforcement mechanisms', in L. Dickens (ed) Making Employment Rights Effective. Oxford: Hart.

Oxford English Dictionary (nd) Concede. Available at: https://en.oxforddictionaries.com/definition/concede. Accessed $5^{\text {th }}$ February 2019.

Oliver, M. (2013), 'The social model of disability: thirty years on', Disability \& Society, 28, 7, 1024-1026.

Roulstone, A. (2003), 'The legal road to rights? Disabling premises, obiter dicta and the Disability Discrimination Act 1995', Disability \& Society, 18, 2, 117-131.

Solanke, I. (2017), Discrimination as Stigma, Portland Hart.

Taylor, A. (2002), 'Medical evidence: crucial in Employment Tribunals', Business Law Review August/September, 209-211.

Van Wanrooy, B., H. Bewley, A. Bryson, et al. (2013), The 2011 Workplace Employment Relations Study First Findings. Swindon: ESRC.

William, L. C. (2016), 'The implementation of equality legislation: the case of disabled graduates and reasonable adjustments', Industrial Relations Journal, 47, 4, 341-359. 


\begin{tabular}{|c|c|c|}
\hline Statutory wrong & Definition & Employer Defence \\
\hline $\begin{array}{l}\text { Direct } \\
\text { discrimination }\end{array}$ & $\begin{array}{l}\text { A claimant suffers less favourable treatment } \\
\text { compared to a non-disabled person }\end{array}$ & None \\
\hline $\begin{array}{l}\text { Indirect } \\
\text { discrimination }\end{array}$ & $\begin{array}{l}\text { The organisation has a provision, criterion or } \\
\text { practice that is facially neutral but places the } \\
\text { disabled person at a disadvantage compared to } \\
\text { non-disabled persons }\end{array}$ & $\begin{array}{l}\text { A proportionate } \\
\text { means of achieving } \\
\text { a legitimate aim }\end{array}$ \\
\hline Harassment & $\begin{array}{l}\text { The claimant's dignity has been violated } \\
\text { and/or he/she has been subject to intimidating, } \\
\text { degrading or offensive environment because } \\
\text { of a disability. }\end{array}$ & $\begin{array}{l}\text { It is not reasonable } \\
\text { for the claimant to } \\
\text { perceive that the } \\
\text { conduct has that } \\
\text { effect. }\end{array}$ \\
\hline Victimisation & $\begin{array}{l}\text { A claimant is subjected to a detriment because } \\
\text { he/she in good faith has done a 'protected act', } \\
\text { e.g. bringing proceedings under the Equality } \\
\text { Act. }\end{array}$ & None \\
\hline $\begin{array}{l}\text { Failure to make a } \\
\text { reasonable } \\
\text { adjustment }\end{array}$ & $\begin{array}{l}\text { The employer has a duty to make adjustments, } \\
\text { e.g. to modify the built environment, or } \\
\text { change working practices/hours, where a } \\
\text { disabled person would be put at a substantial } \\
\text { disadvantage in comparison with non-disabled } \\
\text { people. }\end{array}$ & $\begin{array}{l}\text { It is not reasonable } \\
\text { for this adjustment } \\
\text { to be made, e.g. } \\
\text { because it is too } \\
\text { costly. }\end{array}$ \\
\hline $\begin{array}{l}\text { Discrimination } \\
\text { arising from a } \\
\text { disability }\end{array}$ & $\begin{array}{l}\text { A claimant has been treated unfavourably } \\
\text { because of something arising from their } \\
\text { disability. }\end{array}$ & $\begin{array}{l}\text { A proportionate } \\
\text { means of achieving } \\
\text { a legitimate aim }\end{array}$ \\
\hline
\end{tabular}

Note: The focus in this study is on disabled claimants, so the table excludes associative discrimination, when someone is treated unfairly and directly discriminated or harassed on the basis of another person's protected characteristic, for instance a carer of a disabled person. 


\begin{tabular}{|c|c|c|c|}
\hline \multicolumn{4}{|l|}{ Gender } \\
\hline & Man & 406 & 53.3 \\
\hline & Woman & 355 & 46.6 \\
\hline & Not mentioned & 1 & 0.1 \\
\hline \multicolumn{4}{|l|}{ Sector } \\
\hline & Private & 450 & 59.1 \\
\hline & Public & 298 & 39.1 \\
\hline & Charity & 12 & 1.6 \\
\hline & Not mentioned & 2 & 0.3 \\
\hline \multicolumn{4}{|c|}{ Type of impairment ${ }^{a}$} \\
\hline & Physical impairment & 284 & 37.3 \\
\hline & Sensory impairment & 13 & 1.7 \\
\hline & Mental impairment & 185 & 24.3 \\
\hline & Learning impairment & 24 & 3.1 \\
\hline & Multiple impairments & 64 & 8.4 \\
\hline & Not mentioned & 322 & 42.3 \\
\hline \multicolumn{4}{|c|}{ Claimants' representation at the hearing } \\
\hline & Legal representation & 287 & 37.7 \\
\hline & Lay representation & 76 & 10.0 \\
\hline & Representation by friends or family & 39 & 5.1 \\
\hline & Self representation & 269 & 35.3 \\
\hline & Did not attend and was not represented & 31 & 4.1 \\
\hline & Not mentioned & 60 & 7.9 \\
\hline \multicolumn{4}{|c|}{ Employer's representation at the hearing } \\
\hline & Legal representation & 600 & 78.7 \\
\hline & Lay representation & 58 & 7.6 \\
\hline & $\begin{array}{l}\text { Representation by senior employee in } \\
\text { organisation }\end{array}$ & 16 & 2.1 \\
\hline & Self representation & 2 & 0.3 \\
\hline & Did not attend and was not represented & 12 & 1.6 \\
\hline & Not mentioned & 74 & 9.7 \\
\hline \multicolumn{4}{|c|}{ Types of DDA claims brought ${ }^{b}$} \\
\hline & Direct Discrimination & 242 & 31.8 \\
\hline & Discrimination arising from disability & 327 & 42.9 \\
\hline & Harassment & 119 & 15.6 \\
\hline & Indirect discrimination & 83 & 10.9 \\
\hline & Victimisation & 93 & 12.2 \\
\hline & Failure to provide Reasonable & 336 & 44.1 \\
\hline & Adjustments & & \\
\hline \multicolumn{4}{|c|}{$\begin{array}{l}\text { Cases with claims on other types of } \\
\text { discrimination }^{c}\end{array}$} \\
\hline
\end{tabular}

Note: ${ }^{a}$ For impairments, percentages do not add up to 100 as claimants with more than one impairment (e.g. a physical and a sensory impairment) were included in all relevant categories. ${ }^{\mathrm{b}}$ For DDA claims, percentages do not add up to 100 as claimants could bring more than one DDA claim. ${ }^{\mathrm{c}}$ Other types of discrimination include discrimination on the grounds of age, sex, race, sexual orientation, religion/belief and pregnancy/maternity. 
Table 3: Binary logistic regression predicting 'success at full hearing'

\begin{tabular}{|c|c|c|c|c|c|c|}
\hline & \multicolumn{6}{|c|}{$\begin{array}{c}\text { Overall outcome: } \\
\text { Success at full hearing }\end{array}$} \\
\hline & \multicolumn{3}{|c|}{ Model 1} & \multicolumn{3}{|c|}{ Model 2} \\
\hline & $\boldsymbol{B}$ & $S E$ & $\operatorname{Exp}(b)$ & $\boldsymbol{B}$ & $S E$ & $\operatorname{Exp}(b)$ \\
\hline Constant & -1.03 & $(0.27)$ & 0.36 & -1.24 & $(0.46)$ & 0.29 \\
\hline Gender (1 = woman $)$ & 0.29 & $(0.21)$ & 1.34 & 0.27 & $(0.25)$ & 1.31 \\
\hline Sector $(1=$ private $)$ & -0.12 & $(0.21)$ & 0.88 & 0.11 & $(0.25)$ & 1.12 \\
\hline Equality of arms & $0.47 * * *$ & $(0.10)$ & 1.60 & $0.46 * * *$ & $(0.12)$ & 1.59 \\
\hline $\begin{array}{l}\text { Judge's number of disability } \\
\text { discrimination cases }\end{array}$ & -0.01 & $(002)$ & 0.99 & 002 & $(003)$ & 102 \\
\hline Case includes claims on other types & & & & & & \\
\hline of discrimination $^{\mathrm{a}}(1=$ yes $)$ & $-0.68 *$ & $(0.33)$ & 0.51 & -0.52 & $(0.38)$ & 0.59 \\
\hline Impairment: physical or sensory & & & & 0.06 & $(0.35)$ & 1.06 \\
\hline Impairment: mental & & & & 0.17 & $(0.34)$ & 1.19 \\
\hline Model Chi-square & \multicolumn{3}{|c|}{33.41} & \multicolumn{3}{|c|}{21.68} \\
\hline Df & \multicolumn{3}{|c|}{5} & \multicolumn{3}{|c|}{7} \\
\hline -2 Log likelihood & \multicolumn{3}{|c|}{605.07} & \multicolumn{3}{|c|}{427.45} \\
\hline Nagelkerke's $\mathrm{R}^{2}$ & \multicolumn{3}{|c|}{.08} & \multicolumn{3}{|c|}{.08} \\
\hline Number of cases & \multicolumn{3}{|c|}{669} & \multicolumn{3}{|c|}{425} \\
\hline
\end{tabular}

Notes: Analyses based on all available cases. ${ }^{a}$ Other types of discrimination include discrimination on the grounds of age, sex, race, sexual orientation, religion/belief and pregnancy/maternity.) $* p<0.05$. $* * p<0.01$. $* * * p<0.001$. 


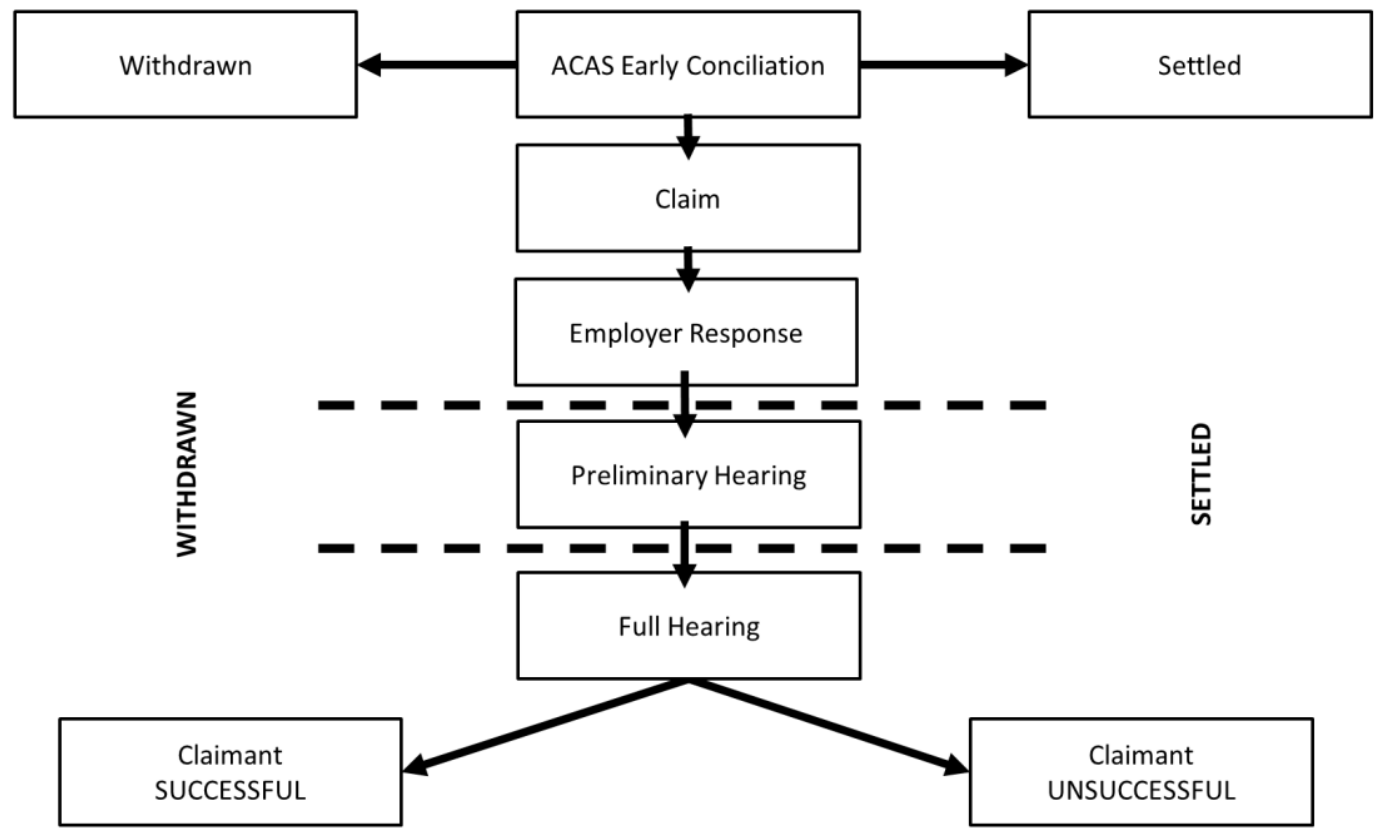

Figure 1: Overview of the Employment Tribunal Process 


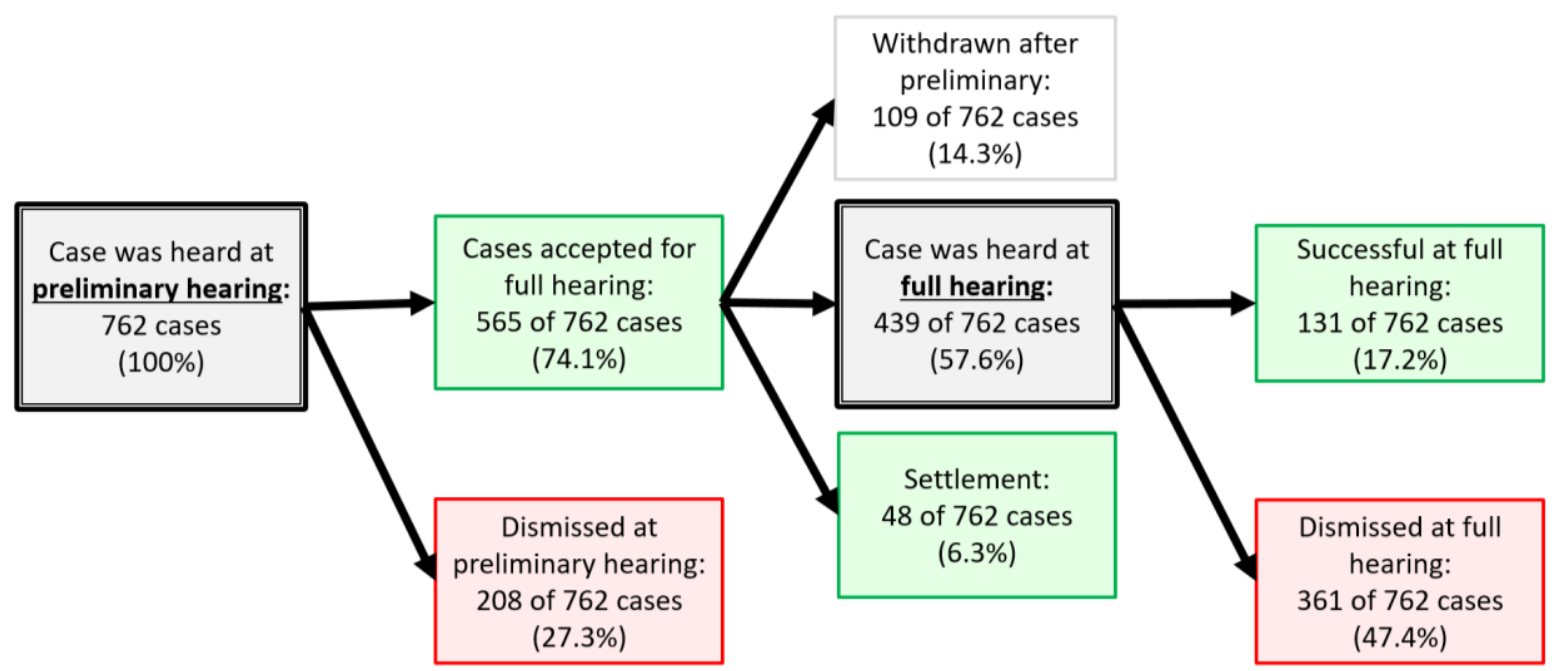

Figure 2: Outline of stages at which discrimination cases fail, with the number and percentage of cases in each category. Note that as part of a case, claimants can bring claims for different types of disability discrimination, which are judged separately. Thus, a claimant may withdraw a claim for indirect discrimination but be successful with a claim for direct discrimination. Consequently, a particular case can appear in different categories. Therefore, the number of cases in the different categories does not add up to 762. 